\title{
INTERAKSI ANTARA BIOMASSA DENGAN UPAYA PENANGKAPAN: STUDI KASUS PERIKANAN PUKAT CINCIN DI PEKALONGAN DAN JUANA
}

\author{
Suherman Banon Atmaja") dan Duto Nugroho")
}

\begin{abstract}
ABSTRAK
Pada perikanan akses terbuka akan terjadi kompetisi bebas terjadi antara perikanan skala besar dan kecil. Kajian stok tidak hanya menduga besaran stok, tetapi juga mengkaji bagaimana respon nelayan ketika kondisi stok menurun dan pendapatan turun di bawah normal. Nelayan dapat dianggap mirip sebagai pemangsa alami, sehingga perilaku upaya penangkapan dan populasi ikan yang dieksploitasi dapat diamati melalui interaksi antara biomassa (sebagai mangsa) dengan upaya penangkapan (sebagai pemangsa). Kondisi stabilitas terjadi pada tingkat upaya catch per unit of effort $\left(U^{*}\right)$ dengan keuntungan $(\pi=0)$, di mana pada kondisi ini tidak ada kapal masuk atau keluar dari usaha perikanan. Lintasan dinamika dari hasil tangkapan berada di atas kurva pertumbuhan bersih, dan bertemu pada titik $(\pi=0)$ yang berbentuk spiral tertutup. Interaksi biomassa dengan upaya penangkapan menunjukkan kenaikan upaya penangkapan akan diikuti dengan penurunan biomassa. Penyusutan nilai biomassa mencapai $66 \%$ menunjukkan bahwa stok ikan pelagis sangat rentan terhadap eksploitasi b rrlebihan. Akan tetapi kemungkinan runtuh secara biologi tidak akan terjadi, karena stabilitas bio ekonomi tidak pernah tercapai. Perpotongan garis linear $(\partial \mathrm{B} / \partial \mathrm{t}=0)$ dan garis $\partial E / \partial t=0$ menerangkan upaya penangkapan meningkat apahila biomassa lebih dari titik stabilitas dan upaya penangkapan menurun apabila biomassa lebih kecil dari titik stabilitas.
\end{abstract}

KATA KUNCI: interaksi, biomassa, upaya penangkapan, pukat cincin, Laut Jawa

ABSTRACT: Interaction between biomass and effort: Case study on purse seine fishery in Pekaiongan and Juana. By: Suherman Banon Atmaja and Duto Nugroho

\begin{abstract}
Under conditions of open access it occurs free competition among large scale and small scale fishing fleets. Study on stocks assessment not only estimates size of stock, but how fishers will response when stock has declined and their income has decreased under some level. The fishers can be assumed like nature predator, so behaviour of eifort ard fish population which was exploited to observe through interaction between biomass (as prey) and effort (as predator). An equilibrium $(\pi=0)$, a point where there will be no entry or exit from fishery. A dynamic trajectory of yield shows yield increases up to sustainable growth curve, and the trajectory of this path form a closing spiral on the equilibrium point $(\pi=0)$. Interaction between biomass and effort showed that increasing effort will response with decreasing biomass. Diminution of biomass reaching $66 \%$ indicated that pelagic fish stock are seen to be susceptible a.ld cannot sustain a high level of fishing. However, biological collapse may be not occurred, because bio economic equilibrium never reached. The two line intersect, curve $\partial B / \partial t=0$ and curve $\partial E / \partial t=0$ explained that effort increases for biomass more than a point equilibrium and effort decreases for biomass iess than a point equilibrium.
\end{abstract}

KEYWORDS: $\quad$ interaction, biomass, effort, purse seine, Java Sea

\section{PENDAHULUAN}

Indikasi lebih tangkap telah banyak dilaporkan oleh peneliti terdahulu. Kenaikan aktivitas penangkapan setelah motorisasi payang pada tahun 1955 telah menurunkan hasil tarigkapan per perahu dari 4 ton per perahu per tahun kada tahun 1940 menjadi 3,13 ton per perahu per tahun pada tahun 1955. Pada tahun 1967, hasil tangkapan 2,6 ton per perahu per tahun. Penurunan ini sebagian disebabkan oleh eksploitasi berlebihan dan salah mengelola atas daerah penangkapan ikan sepanjang pesisir utara Pulau Jawa. Pendistribusian upaya penangkapan yang tidak merata, di mana penggunaan teknologi penangkapan yang modern (perahu motor bertambah) dan sebaliknya perahu layar tradisional mengalami penurunan (Collier, 1981). Sujastani
(1978); Nurhakim, et al. (1995) mengatakan bahwa perikanan pelagis di daerah penangkapan tradisional telah mencapai tingkat eksploitasi yang mengarah lebih tangkap. Mc Elroy et al. (1991) menyimpulkan bahwa spesies ikan pelagis kecil yang merupakan hasil tangkapan pukat cincin telah lebih tangkap tidak di daerah penangkapan pesisir pantai utara Pulau Jawa, tetapi hampir di seluruh Laut Jawa. Tingkat eksploitasi perikanan pukat cincin berdasarkan pada sumber data dari tempat penangkapan ikan Pekalongan berada di tingkat eksploitasi yang optimum (Atmaja et al., 2002).

Dalam kajian stok ikan diperoleh hasil dan kesimpulan berbeda adalah suatu hal yang wajar. Charles (2001) mengatakan bahwa realitisnya tidak ada dalam perikanan dapat diukur sempurna. Sumber

\footnotetext{
.) Peneliti pada Balai Riset Perikanan Laut, Jakarta

") Peneliti pada Pusat Riset Perikanan Tangkap, Jakarta
} 
ketidakpastian dalam sistem perikanan, yaitu sumber alam (besaran stok dan stuktur umur, kematian alami, migrasi, dan parameter stok rekruitmen, interaksi dari multi spesies, interaksi lingkungan dengan ikan), sumber manusia (perubahan teknologi, harga ikan, dan struktur pasar, biaya operasional dan opportunity, persepsi status stok). Cunningham (1981); Hilborn \& Walters (1992) menyarankan bahwa maximum sustainable yield sebagai titik sasaran acuan pengelolaan hanya dapat digunakan dalam jangka pendek. Jika diberlakukan untuk jangka panjang tanpa mempertimbangkan dinamika perikanan akan menghasilkan a false summit dari dugaan besaran hasil tangkapan lestari. Garcia (1986) mengatakan bahwa mengunakan serial data yang lama, tidak melibatkan perilaku nelayan dan dinamika kecepatan penangkapan akan menjadi sumber bias. Komponen ketidakpastian dialamatkan terhadap realibilitas dan tingkat kepercayaan struktur model dan pendugaan parameter (Caddy \& Mcgarney, 1996).

Pada dasarnya sumber daya perikanan adalah sumber daya yang dinamis, komunitas ikan mendiami suatu karakteristik ekosistem yang dikontrol oleh kaidah bio fisik, di sana hidup berdampingan pemangsa alami (predator) dengan mangsa (prey). Dengan pandangan sederhana, bahwa nelayan sebagai pemangsa baru yang memasuki sistem tersebut. Dalam konteks perikanan multi species, nelayan sebetulnya adalah pemangsa jenis lain yang memasuki keseimbangan ekologis dari komunitas ikan. Kegiatan penangkapan akan menyebabkan populasi ikan mencapai keseimbangan baru pada tingkat kepadatan yang lebih rendah. Perbedaan keseimbangan baru dengan yang lama tergantung intensitas penangkapan. Penurunan spesies tertentu akan menyebabkan kekosongan niche ekologi yang kerapkali digantikan sementara oleh spesies lainnya (Laevastu \& Favorite, 1988). Suatu fenomena alami yang umum terjadi dari hubungan antara pemangsa dengan mangsa, penurunan mangsa akan diikuti dengan penurunan pemangsa. Alterasi spesies dan kompetisi spesies ikan pelagis (interspesific competition) ditunjukkan oleh perubahan komposisi hasil tangkapan, di daerah penangkapan bagian timur Laut Jawa selama 3 tahun terakhir ini. Kejadian melimpahnya hasil tangkapan ikan ayam-ayaman (leather jacket, Alusterus monoceros) ketika puncak musim ikan layang atau adanya perubahan sasaran ikan yang menjadi tujuan akibat sudah terbatasnya stok ikan layang (Atmaja et al., 2003).

Hilborn \& Walters (1992) mengatakan bahwa sesungguhnya nelayan dapat dianggap mirip sebagai predator alami, variasi model produksi surplus adalah dinamika biomassa untuk mengamati perilaku populasi terhadap eksploitasi. Kendatipun sumber daya ikan dikategorikan sumber daya yang dapat pulih, bukan berarti tidak terbatas. Apabila kapasitas penangkapan tidak sebanding dengan potensi perikanan yang tersedia, maka yang akan terjadi penyusutan sumber daya ikan dan degradasi lingkungan.

Hampir sebagian besar usaha perikanan tangkap di Indonesia mempunyai karakteristik akses terbuka tanpa pembatasan upaya penangkapan, kompetisi bebas terjadi antara perikanan skala besar dan kecil. Dengan kerangka acuan pengelolaan sumber daya ikan berdasarkan pada target titik acuan kriteria maksimum atau opitimasi dari maximum sustainable yield disebut juga target reference point. Pendekatan tersebut belum dapat menjawab permasalahan yang ada karena mengabaikarı ketidakstabilan maximum sustainable yield, laju pertumbuhan stok ikan dan dinamika usaha perikanan. Kelimpahan stok ikan merupakan kuantitas yang berubah akibat faktor exogeneous dan endogeneous yang belum sepenuhnya dipahami. Selain itu, kajian stok ikan selama ini mengabaikan bagaimana nelayan akan merespon kondisi stok yang telah menyusut dan kondisi kritis ketika pendapatan nelayan menurun di bawah tingkat wajar. Pada kondisi sumber daya ikan yang semakin terbatas, maka tingkat pemanfaatan akan dibatasi oleh tingkat keuntungan atau penurunan upaya penangkapan akan terjadi secara alami.

Tulisan ini menerangkan interaksi antara biomassa dengan upaya penangkapan perikanan pukat cincin, serta reaksi nelayan yang dapat diramalkan untuk tujuan pengelolaan. Penelitian berdasarkan pada hipotesis bahwa sumber daya perikanan adalah merupakan sumber daya yang dinamis, di mana stok ikan dapat bertambah dan berkurang baik secara alamiah maupun akibat eksploitasi.

\section{BAHAN DAN METODE}

Data dikumpulkan dari hasil tangkapan pukat cincin komersial yang berpangkalan di Pekalongan dan Juana selama periode tahun 1976 sampai dengan 2004 , data tersebut mewakili sekitar $25 \%$ dari hasil tangkapan ikan pelagis yang tertangkap di Laut Jawa. Data aspek operasional berdasarkan pada wawancara yang meliputi total biaya selama operasi penangkapan (biaya yang akan digunakan pada saat perhitungan bagi hasil), daerah penangkapan, jumlah hari operasi penangkapan. Delapan puluh tiga kapal contoh, semuanya beroperasi di Laut Jawa dan Selat Makassar (Lampiran 2).

Pada model Schaefer, laju pertumbuhan bersih stok ikan digambarkan sebagai fungsi logistik $F(B)$. Perubahan stok ikan per waktu setelah dilakukan penangkapan adalah selisih antara laju pertumbuhan stok dikurangi dengan hasil tangkapan (C) secara matematik dapat ditulis:

$$
\begin{aligned}
& F(B)=\partial B / \partial t=r B_{t}\left(1-B_{t} / B_{\infty}\right)-C \\
& \Delta B / \Delta t=r B_{t}\left(1-B_{t} / B_{\infty}\right)-C \ldots \ldots .
\end{aligned}
$$


Jika $\Delta t=1$ tahun dan besarnya hasil tangkapan (C) berbanding lurus dengan biomassa $(B)$, tingkat upaya penangkapan (E) dan koefisien kemampuan tangkap (q), $C=q E B$, maka:

$$
\begin{aligned}
& B_{t+1}-B_{t}=r B_{t}\left(1-B_{t} / B_{\infty}\right)-C \\
& \text { atau } \\
& B_{t+1}-B_{t}=r B_{t}\left(1-B_{t} / B_{\infty}\right)-q^{\star} B_{t} E_{t}
\end{aligned}
$$

Analisis dinamik dalam penelitian ini dilakukan dengan 2 cara, yaitu:

1. Model Willen's open access dynamic ditulis sebagai berikut:

$$
\begin{aligned}
& \partial B / \partial t=r B_{t}\left(1-B_{t} / B_{\infty}\right)-q B_{t} E . \\
& \partial E / \partial t=s\left(p q B_{t}-c\right) E
\end{aligned}
$$

Kondisi keseimbangan terjadi pada perpotongan dari hubungan biomassa dengan upaya penangkapan besifat linear $(\partial \mathrm{B} / \partial \mathrm{t}=0)$ dan garis $\partial \mathrm{E} / \partial \mathrm{t}=0$.

2. Perilaku biomassa yang bereaksi terhadap eksploitasi berdasarkan pada Hilborn \& Walters (1992) sebagai berikut:

$$
E_{t+1}=E_{t}\left(1+s\left(U_{t}-U^{\star}\right)\right.
$$

Dalam perikanan open access, suatu perikanan akan mencapai titik keseimbangan pada tingkat upaya penangkapan $\left(E^{*}\right)$, di mana penerimaan total $\left(T R=p^{*} C\right)$ sama dengan biaya total $\left(T C=c^{*} E\right)$, berdasarkan pada persamaan sebagai berikut:

$$
\pi=p^{\star} C-c^{\star} E
$$

di mana

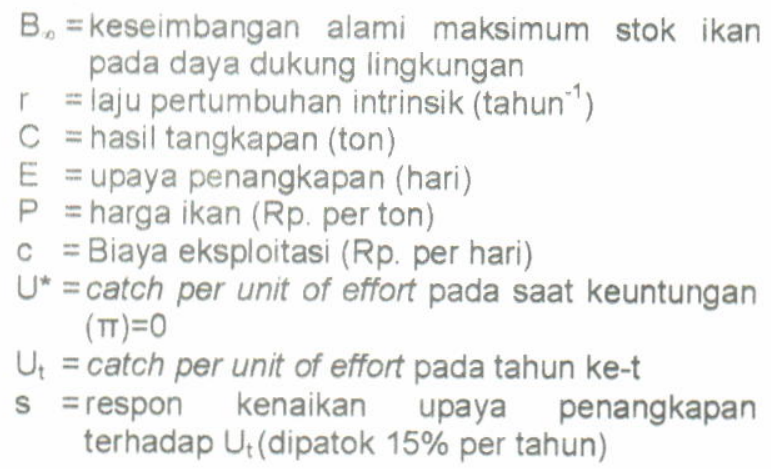

\section{HASIL DAN BAHASAN}

\section{Status Perikanan}

Selama 3 dekade pukat cincin mengeksploitasi sumber daya ikan pelagis kecil di Laut Jawa dan sekitarnya telah berkembang sangat dinamis Berdasarkan pada dinamika perkembangnya perikanan pukat cincin dapat dikelompokkan menjadi 3 runtun waktu, yaitu runtun waktu tahun 1976 sampai dengan 1981, runtun waktu tahun 1982 sampai derigan 1990, dan runtun waktu tahun 1991 sampai dengan 2004. Runtun waktu tahun 1976 sampai dengan 1982 merupakan periode sebelum pelarangan alat tangkap trawl, di mana sebagian besar nelayan pukat cincin beroperasi di daerah penangkapan tradisional, taktik penangkapan menggunakan rumpon. Runtun waktu tahun 1982 sampai dengan 1990 merupakan periode nelayan pukat cincin sudah memperluas daerah operasi ke bagian timur Laut Jawa dan Selat Makassar dengan taktik penangkapannya menggunakan rumpon ditanam di laut, sebagian kapal mulai menggunakan lampu sorot halogen dan mercuri sebagai alat bantu utama menggantikan rumpon. Runtun waktu tahun 1991 sampai dengan 2004 adalah periode di mana sebagian besar taktik penangkapan telah menggunakan lampu sorot. Berdasarkan pada tahapan perkembangan perikanan pukat cincin dibagi menjadi 2 tahapan, yaitu runtun waktu tahun 1976 sampai dengan 1987 dan runtun waktu tahun 1988 sampai dengan 2004. Runtun waktu tahun 1976 sampai dengan 1987 adalah tahap growth and decline yang merupakan aktivitas perluasan daerah penangkapan. Runtun waktu tahun 1988 sampai dengan 2004 adalah merupakan tahapan cycles, yaitu inovasi melalui perubahan taktik penangkapan dari rumpon menjadi lampu sorot sebagai alat bantu utama pengumpulan ikan, serta pada tahun 1997 dilengkapi dengan penentu posisi (GPS) dan fish finder (Atmaja et al., 2003).

Perhitungan bagaimana hasil tangkapan mempengaruhi populasi ikan mengikuti dinamika perilaku biomassa. Perubahan kelimpahan stok ikan dipengaruhi 3 parameter dari produksi surplus Schaefer, yaitu pertumbuhan intrinsik (r), carring capacity $\left(\mathrm{B}_{\infty}\right)$, dan koefisien kemampuan tangkap $(q)$. Pendugaan parameter produksi surplus ( $r, q$, dan $K$ ) secara terpisah menggunakan prosedur Walters \& Hilborn (1976) dalam Hilborn \& Walters (1992) dari sumber data tahun 1990 sampai dengan 2004 (Lampiran 1) yang diterakan pada Tabel 1

Secara teoritis, tingkat keuntungan $(\pi=0)$ pada perikanan pukat cincin terjadi pada $U^{*}=0,6$ ton per hari yang diperoleh dari rasio harga ikan dengan biaya eksploitasi (Tabel 2).

Dengan mengalikan hasil tangkapan lestari (dari fungsi logistik) dengan harga ikan diperoleh kurva sustainable revenue $\left(T R=p^{\star} C\right.$, di mana $C$ adalah hasil tangkapan lestari). Demikian pula, dengan mengalikan biaya per satuan input dengan upaya penangkapan diperoleh total biaya $\left(\mathrm{TC}=\mathrm{C}^{\star} \mathrm{E}\right)$ yang linear terhadap upaya penangkapan. Penggabungan kurva sustainable revenue dan total biaya tersebut dalam suatu gambar, akan diperoleh sebagaimana diterakan pada Gambar 1. Titik perpotongan menerangkan titik keseimbangan, di mana penerimaan total (TR) sama dengan biaya total (TR) 
Tabel 1. Parameter produksi surplus (model pertumbuhan logistik)

Table 1. Parameters of surplus production (logistic growth model)

\begin{tabular}{cccccccc}
\hline Periode & $\begin{array}{c}\beta_{0}= \\
\mathrm{r}\end{array}$ & $\begin{array}{c}-\beta_{1}= \\
\mathrm{r} /\left(\mathrm{gB}_{\infty}\right)\end{array}$ & $\begin{array}{c}-\beta_{2}= \\
(\mathrm{q})\end{array}$ & $\begin{array}{c}\mathrm{B}_{\infty} \\
(\text { ton) }\end{array}$ & $\begin{array}{c}\text { MSY } \\
(\text { ton })\end{array}$ & $\begin{array}{c}\text { Koefisien } \\
\text { determinasi }\left(\mathrm{R}^{2}\right)\end{array}$ & Uji F \\
\hline $1990-2004$ & 1,048 & 0,3757 & $6,910^{-6}$ & 405.000 & 106.000 & $50 \%$ & $*$ \\
\hline
\end{tabular}

Tabel 2. Perhitungan $U^{*}$ (catch per unit of effort) ketika keuntungan $(\pi=0)$ pada perikanan pukat cincin Table 2. Calculation $U^{*}$ (catch per unit of effort) when profit $(\pi=0)$ on purse seine fisheries

\begin{tabular}{lcccccc}
\hline & $\begin{array}{c}\text { Harga ikan } \\
\text { (Rp. juta } \\
\text { per ton) }\end{array}$ & $\begin{array}{c}\text { Biaya eksploitasi } \\
\text { (Rp. juta per hari) }\end{array}$ & $\begin{array}{c}\mathrm{B}^{*}=\mathrm{c} / \mathrm{pq} \\
\text { (ton) }\end{array}$ & $\begin{array}{c}\mathrm{E}^{*}= \\
\mathrm{r} / \mathrm{q}\left(1-\mathrm{B}^{*} / \mathrm{B}_{\infty}\right) \\
\text { (hari) }\end{array}$ & $\begin{array}{c}\mathrm{C}^{*}= \\
\mathrm{rB}^{*}(\mathbf{1}- \\
\left.\mathbf{B}^{*} / \mathrm{B}_{\infty}\right) \\
\text { (ton) }\end{array}$ & $\begin{array}{c}\mathrm{U}^{*}=\mathrm{C}^{*} / \mathrm{E}^{*} \\
\text { (ton per hari) }\end{array}$ \\
\hline Rata-rata & 2,95 & 1,87 & 92.000 & 118.000 & 74.000 & 0,63 \\
$\mathrm{SD}$ & 1,02 & 0,86 & & & 7.000 \\
$\mathrm{~N}$ & 88 & 88 & &
\end{tabular}

atau tingkat keuntungan $(\pi)=0$. Tingkat upaya penangkapan $\left(\mathrm{E}^{*}\right)$ pada posisi ini tingkat upaya penangkapan keseimbangan yang oleh Gordon dalam Fauzi (2000) disebut sebagai bioeconomic equilibrium of open access, di mana pada tingkat upaya penangkapan $\left(E^{*}\right)$ keseimbangan tercapai sehingga entry dan exit tidak terjadi.

Pada Gambar 1 terdapat 3 titik keseimbangan, yaitu a) titik keseimbangan berdasarkan pada Tabel 2 $\left(U^{*}=0,6\right.$ ton per hari); b) perpotongan kurva sustainable revenue (TR) dengan biaya total pada sudut $45^{\circ}$, terjadi pada $U^{*}=0,7$ ton per hari; dan c) titik keseimbangan realitis perikanan yang sebenarnya berada $\left(U^{*}=1\right.$ ton per hari).

Kondisi keseimbangan $\left(\cup^{*}=0,6\right.$ ton per hari) kemungkinan tidak pernah tercapai, karena berdasarkan pada aktivitas penangkapan armada pukat cincin yang cenderung menurun, terutama rata- rata trip per kapal dan jumlah hari operasi semakin lama. Penurunan rata-rata trip per kapal dapat diartikan semakin banyak kapal yang tidak melaut (hanya bertambat di pelabuhan) (Atmaja et al., 2002).

Plot tumpah tindih kurva pertumbuhan bersih dan hubungan biomassa hasil tangkapan (Gambar 2) menunjukkan titik perpotongan antara kurva pertumbuhan bersih (a) dengan garis penurunan hasil tangkapan tahun 1998 dan hasil tangkapan tahun 1999 berada pada posisi hasil tangkapan (99.000 ton) dan biomassa ( 140.000 ton) (35\% dari biomassa awal).

Trajektori dinamik hasil tangkapan $U^{*}=1$ ton per hari (Gambar 2) dan $U^{*}=0,6$ ton per hari (Gambar 2 c) menunjukkan lintasan dinamik hasil tangkapan melingkar berbentuk spiral tertutup dan berpotongan dengan kurva pertumbuhan bersih (Gambar 2a). Trajektori dinamis antara upaya penangkapan dan biomassa disajikan pada Gambar 3.

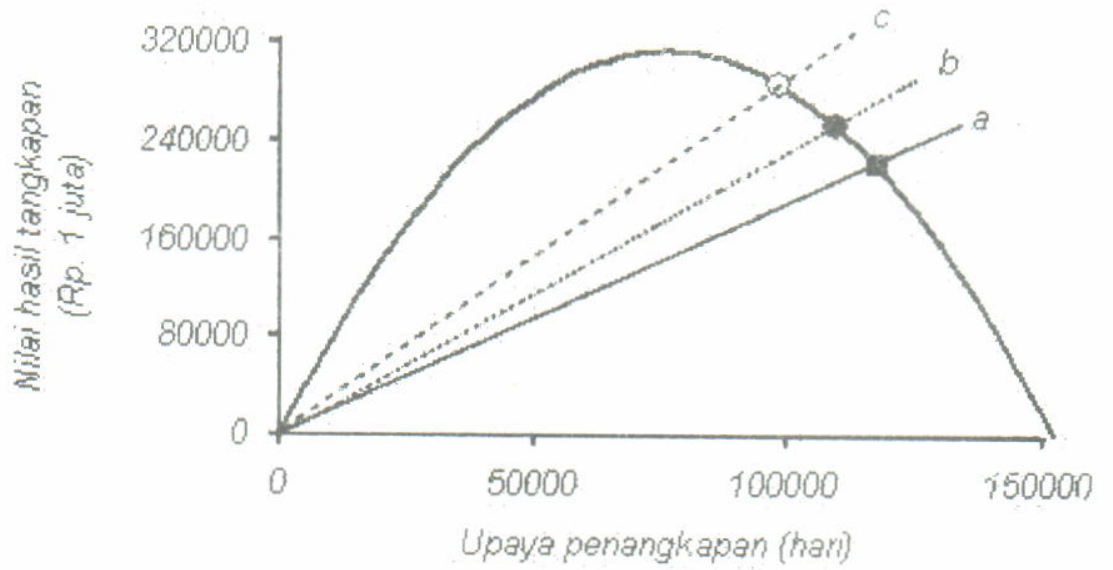

Gambar 1. Kurva sustainable revenue dan biaya total operasional pukat cincin.

Figure 1. (Keterangan: a) $U^{*}=0,6$ ton; b) $U^{*}=0,7$ ton (sudut $45^{\circ}$ ); dan c) $U^{*}=1$ ton)

Sustainable revenue curve and total operational cost of purse seiner.

(Remarks: a) $U^{*}=0,6$ ton; b) $U^{*}=0,7$ ton (angle $45^{\circ}$ line); and c) $U^{*}=1$ ton) 


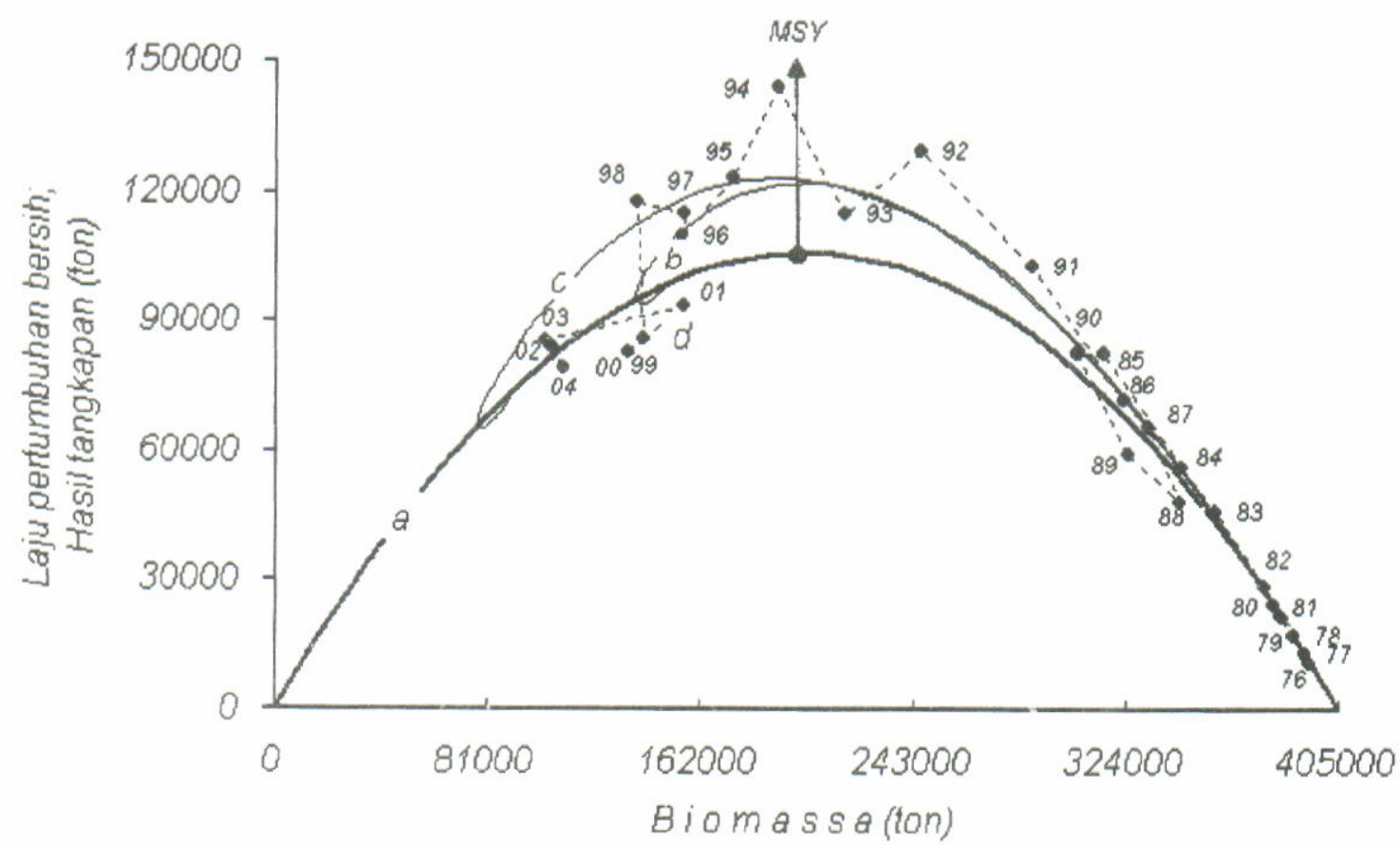

Gambar 2. Plot tumpang tindih kurva pertumbuhan bersih stok (a); hubungan antara dinamik hasil tangkapan dengan biomassa, nilai $U^{*}=1(b) ; U^{*}=0,6(c)$; dan hubungan antara biomasa dengan hasil tangkapan actual (d).

Figure 2. Overlapping of stok's net growth (a); relationship between a dynamics of catch and biomass; $U^{*}=1(b) ; U^{*}=0,6(c)$; and relationship between biomass and actual cacth (d).

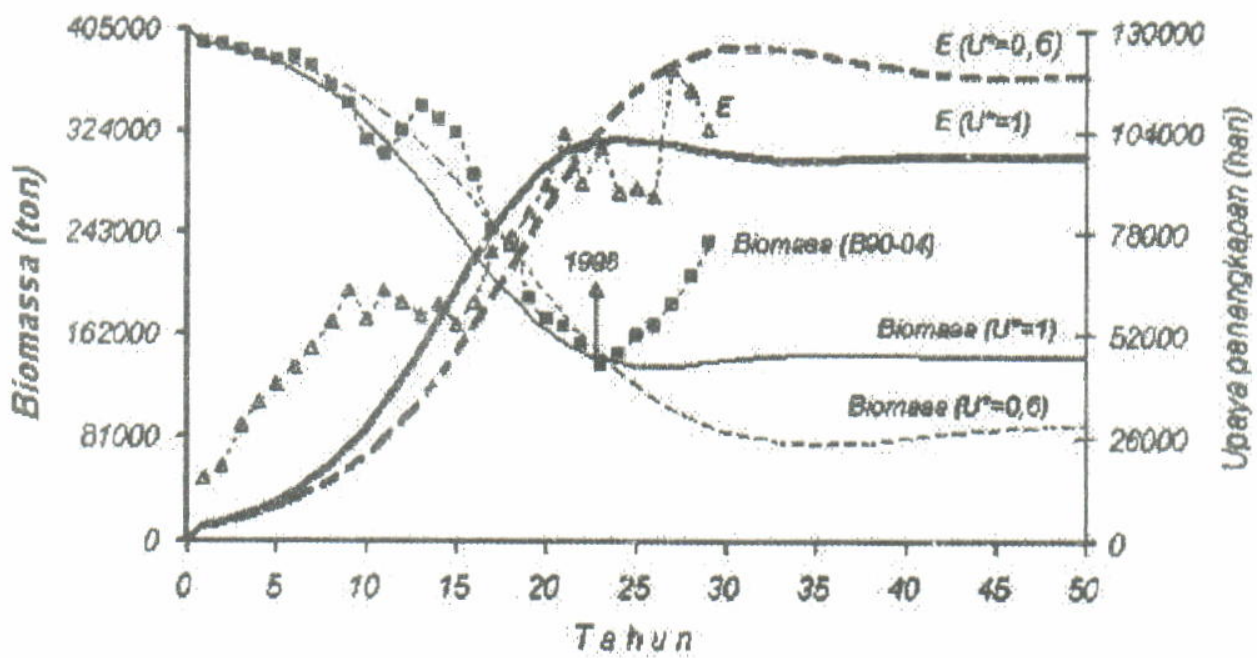

Gambar 3. Trajektori dinamis antara upaya penangkapan dan biomassa.

Figure 3. $\quad$ Dynamics trajectory between e.fort and biomass.

(Remarks: $E$ = actual effort)

Dari Gambar 3 tersebut terlihat interaksi berlawanan antara upaya penangkapan dengan biomassa. Ketika upaya penangkapan meningkat, biomassa mulai mengalami penurunan sampai dengan tersisa $34 \%$ dari biomassa awal, tetapi penurunan upaya penangkapan sangat lambat $5 \%$, begitu juga pulihnya biomassa sangat lambat $(4,5 \%)$. Trend biomassa (B90-04) memperlihatkan setelah terjadinya penurunan biomassa sekitar $65 \%$ pada tahun 1998 (tahun ke-23), biomassa cenderung pulih sangat cepat. Bagi trajektori trend biomassa $\left(U^{*}=1\right)$ terus mengalami penurunan sampai dengan tahun ke25 dan untuk biomassa $\left(U^{*}=0,6\right)$ terus mengalami penurunan sampai dengan tahun ke-34 dan kepulihan biomassa terlihat sangat lambat. Dengan demikian, hasil tersebut mempertegas bahwa kenaikan 
biomassa (B90-04) setelah tahun 1998 adalah semu (quasi recovery). Secara teoritis, peningkatan biomassa seharusnya kapal memasuki perikanan juga meningkat, dirangsang dengan kenaikan hasil tangkapan per satuan upaya. Sebaliknya, realitis perikanan pukat cincin selama 5 tahun terakhir ini telah melakukan penurunan aktivitas penangkapan, rata-rata hari beroperasi cenderung terus meningkat dan nelayan merasakan semakin sulit menemukan gerombolan ikan. Selain itu, penyusutan stok akan direspon dengan peningkatan kemampuan penangkapan ikan melalui perbaikan dan inovasi teknologi yang lebih maju yakni penggunaan jumlah lampu sorot peningkatan tanpa kendali (Atmaja, 2002).

Perkembangan rata-rata trip per kapal cenderung menurun, tetapi jumiah hari operasi terus meningkat (Atmaja, et al. 2003). Penurunan upaya penangkapan, terutama hari operasi sulit dilakukan karena pemilik atau nakhoda kapal lebih berorientasi terhadap keuntungan tiap tripnya. Walaupun demikian, penurunan hasil tangkapan teiah menyebabkan beberapa kapal pukat cincin diubah alat tangkap menggunakan cantrang. Dengan demikian, pada kondisi sumber daya ikan yang semakin terbatas, maka tingkat pemanfaatan akan dibatasi oleh tingkat keuntungan. Apabila biaya eksploitasi dan beban biaya kerja yang harus ditanggung lebih besar dari pada nilai hasil tangkapan, maka beberapa pengusaha akan keluar dari usaha penangkapan atau untuk sementara kapal berhenti beroperasi

Kasus keluarnya pengusaha dari usaha penangkapan akibat penurunan keuntungan terjadi pada kelompok usaha perikanan Margo. Kelompok ini adalah pelopor penggunaan alat bantu pengumpul ikan berupa lampu sorot (cahaya) di atas 20.000 watt dengan menggunakan kapasitas kapal yang lebih besar yaitu ukuran kapal >100 GT dan kekuatan mesin $>300$ PK. Pada awalnya keberhasilan berkompetisi penggunaan lampu sorot dan ditunjang dengan kemampuan kapal untuk memperluas dan mencari daerah penangkapan baru adalah faktor utama kesuksesan usaha perikanan kelompok Margo. Pada tahun 1997 atau 1998 jumlah kapal kelompok Margo yang aktif 22 kapal, tahun 2002 jumlah kapal menurun menjadi 17 kapal yang aktif, tahun 2003 hanya $10 \mathrm{kapal}$ yang aktif dengan rata-rata 5,1 trip per kapal dan selama tahun 2004 jumlah kapal yang aktif hanya tersisa 6 kapal dengan rata-rata 3 trip per kapal (Tabel 3).

Selanjutnya, untuk menganalisis interaksi biomassa dengan upaya penangkapan dilakukan melalui pendekatan Model Willen's open access dynamic. Dengan asumsi, bahwa alat tangkap pukat cincin adalah standar dengan kemampuan daya tangkap (koefisien q) yang konstan, dan catch per unit of effort adalah indeks kelimpahan stok ikan di alam. Catch per unit of effort proporsional dengan biomassa $(\mathrm{C}=\mathrm{qEB}$ atau $\mathrm{C} / \mathrm{E}=\mathrm{qB})$, maka penurunan catch per unit of effort mengindikasikan juga penurunan biomassa. Dengan demikian, kenaikan biomassa sejak tahun 1998 dikoreksi dengan $F=q E$ dan $B=C / F$. Selanjutnya, upaya penangkapan diboboti dengan koefisien q dari hasil analisis produksi surplus, yaitu $E=F / q$

Kondisi stabilitas terjadi pada perpotongan kurva yang besifat linear (isocline $\partial \mathrm{B} / \partial \mathrm{t}=0$ ) dengan garis isocline $\partial E / \partial t=0$. Perpotongan $k e-2$ garis tersebut pada titik $F$ menunjukkan tidak akan ada kapal masuk atau keluar dari usaha perikanan (Gambar 4). Pada Gambar tersebut menerangkan adanya respon yang berlawanan antara upaya penangkapan (input) dan kontraksi sumber daya ikan. Pada kondisi ekspansi upaya penangkapan setelah mencapai titik keseimbangan, maka akan terjadi kontraksi dari sumber daya ikan yang cenderung menurun.

Pada Gambar tersebut menerangkan kenaikan upaya penangkapan lebih dari upaya penangkapan pada titik $F$ dan upaya penangkapan menurun pada biomassa kurang dari biomassa pada titik $F$. Sebaliknya, tingkat biomassa lebih dari biomassa pada titik $F$ dengan upaya penangkapan berada di atas isocline $\partial \mathrm{B} / \partial \mathrm{t}=0$, dengan demikian stok yang turun terus-menerus disebabkan oleh hasil tangkapan telah melampui pertumbuhan bersih

Pergerakkan dari variabel biomassa dan upaya penangkapan dibagi menjadi 4 kuadran, yaitu 1) kuadran I, apabila jika upaya penangkapan naik, maka biomassa akan menurun (anak panah horisontal bergerak ke sebelah kiri); 2) kuadran II, apabila biomassa kurang dari biomassa pada titik $F$

Tabel 3

Aktivitas Kapal Margo, rata-rata hasil tangkapan per trip dan nilai produksi selama tahun 2002 sampai dengan 2004 Table 3. Activities vessel of Margo, average catch by trip and average value production by trip, during
periods 2002 to 2004

\begin{tabular}{lccc} 
& $\mathbf{2 0 0 2}$ & $\mathbf{2 0 0 3}$ & $\mathbf{2 0 0}^{*}$ \\
\hline Jumlah kapal & 17 & 10 & 6 \\
Trip per kapal & 6,4 & 5,1 & 3 \\
Rata-rata hasil tangkapan (ton) & 20,5 & 19,4 & 38,2 \\
Rata-rata nilai produksi (Rp. juta) & 63,8 & 65,4 & 97,7 \\
\hline Keterangan/Remarks: ${ }^{*}$ = hanya beroperasi pada bulan September sampai dengan Januari & \\
\hline
\end{tabular}

(Sumber/Sources: Buku mingguan PPI JUANA) 


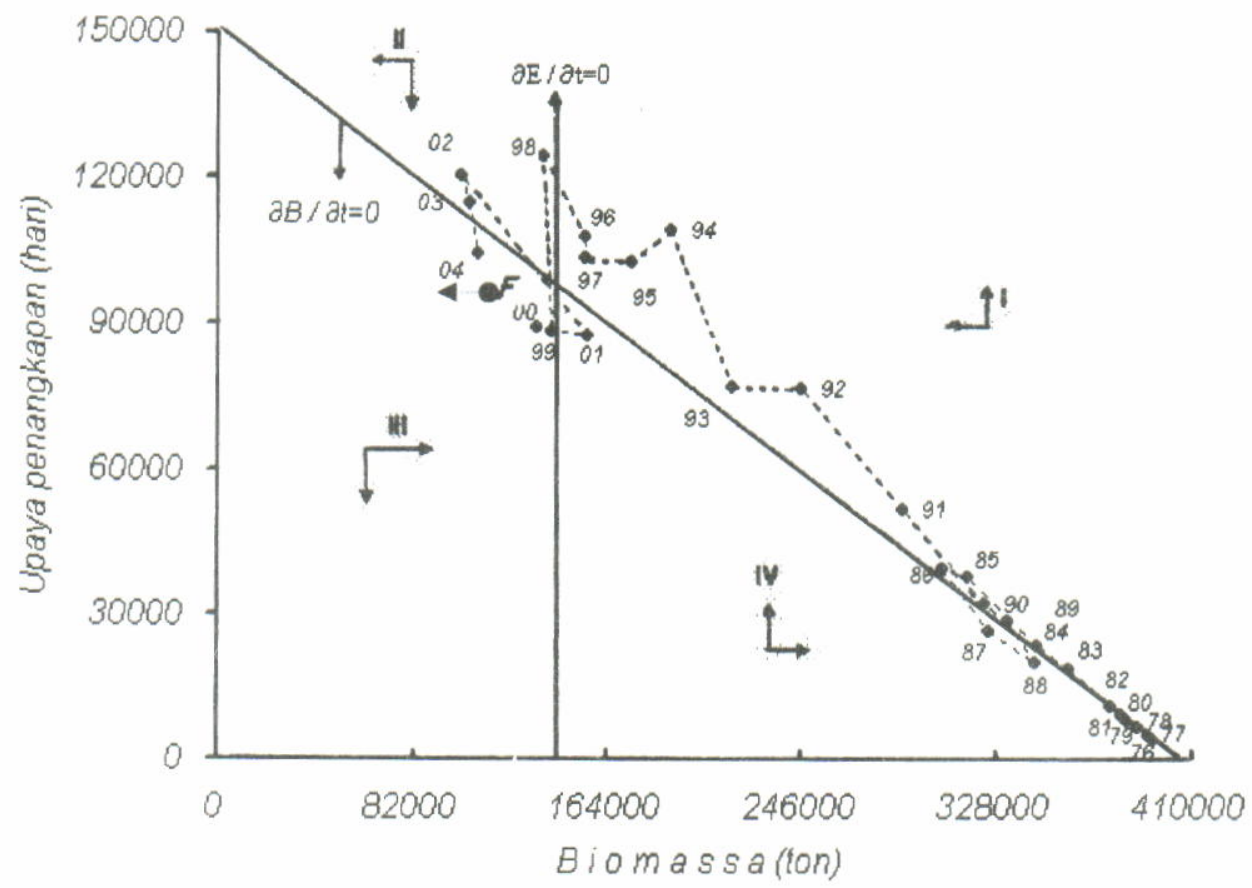

Gambar 4. Isocline biomassa dan upaya penangkapan dalam kondisi keseimbangan. Figure 4. Biomass isocline and effort at equilibrium condition.

dan upaya penangkapan lebih dari upaya penangkapan pada titik $F$, maka stok tidak menguntungkan uniuk diusahakan, dengan demikian akan terjadi armada keluar dari usaha perikanan. Penurunan upaya penangkapan (arah anak panah vertikal turun dan anak panah horisontal bergerak ke sebelah kiri $(\partial E / \partial t=0)$. Pada kondisi stok ikar, telah mengalami overfishing, maka penurunan upaya penangkapan tidak memungkinkan stok untuk pulih; 3) kuadran III, penurunan upaya penangkapan menyebabkan biomassa akan meningkat kembali; dan 4) kuadran IV, kenaikan upaya penangkapan tidak akan menyebabkan menurunkan biomassa, karena pada kondisi hasil tangkapan di bawah laju pertumbuhan bersih (anak panah hurisontal di bawah garis $(\partial \mathrm{B} / \partial \mathrm{t}=0)$ bergerak ke sebelah kanan).

Dari uraian di atas dan situasi perikanan pukat cincin semi industri sudah berada di posisi kuadran II. Penurunan upaya penangkapan pada tahun 2000 sampai dengan 2001 dan biomassa mulai sedikit pulih, kembali ekspansi terjadi. Dengan membiarkan perikanan dalam kondisi upaya penangkapan saat ini dan peningkatan efisiensi penangkapan melalui modernisasi teknologi penangkapan dalam bentuk peralatan bantu penangkapan lampu sorot, GPS dan echo sounder, sulit meningkatkan hasil tangkapan dalam jangka pendek. Bagaimanapun perikanan pelagis kecil di Laut Jawa telah mengalami kelebihan kapasitas penangkapan dan kondisi stok ikan pelagis telah menurun drastis. Hal ini, berarti bahwa kebijakan pengurangan kapasitas seyogyanya segera dilakukan oleh otoritas perikanan. Kebijakan rasionalisasi upaya dan taktik penangkapan, solusi jangka pendek melalui regulasi tidak harus membekukan upaya penangkapan dan jumlah kapal yany ada, tetapi membatasi akses kapal baru. Jangka panjang melalui regulasi mengenai peningkatan taktik penangkapan dan mengontrol penggunaan jumlah lampu sorot.

\section{KESIMPULAN}

Dari hasil penelitian dapat ditarik kesimpulan sebagai berikut:

1. Dengan asumsi bahwa catch per unit of effort proporsional dengan biomassa, penurunan catch per unit of effort mengindikasikan juga penurunan biomassa. Realitis perikanan pukat cincin selama 5 tahun terakhir ini telah melakukan penurunan aktivitas penangkapan, rata-rata hari beroperasi cenderung terus meningkat dan nelayan merasakan semakin sulit menemukan gerombolan ikan. Selain itu, penyusutan stok akan direspon dengan peningkatan kemampuan penangkapan ikan melalui perbaikan dan inovasi teknologi yang lebih maju yakni penggunaan jumlah lampu sorot cenderung meningkat. Dengan demikian, kenaikan biomassa (B90-04) setelah tahun 1998 adalah semu (quasi recovery).

2. Perikanan tangkap diatur dalam kondisi quasi open access, yang menyebabkan sulitnya pengendalian faktor input (upaya dan taktik penangkapan). Namun demikian, upaya perangkapan akan bergerak mengikuti perubahan-perubahan yang terjadi pada sumber 
daya ikan dan faktor eksternal lainnya. Pada tingkat biomassa tidak dapat mendukung pada tingkat upaya penangkapan yang sedang berjalan, maka upaya penangkapan akan berkurang secara alami. Kontrol input effort dilakukan langsung oleh nelayan dan individu pemilik kapal, berdasarkan pada kriteria tingkat keuntungan (rasio biaya operasional dengan pendapatan).

3. Perikanan pelagis kecil di Laut Jawa telah mengalami kelebihan kapasitas penangkapan dan kondisi stok ikan pelagis telah menurun drastis. Biomassa menurun mencapai $66 \%$ dari biomassa awal. Stok ikan pelagis kecil sangat rentan terhadap eksploitasi berlebihan.

4. Dari hasil penelitian dapat digunakan sebaga indikator dari status sumber daya ikan peiagis di Laut Jawa dan sinyal bahwa perikanan pelagis kecil telah overfishing, baik secara biologi maupun ekonomi.

\section{DAFTAR PUSTAKA}

Atmaja, S. B. 2002. Dinamika perikanan purse seine di Laut Jawa dan sekitarnya. Tesis Pascasarjana TKL Institut Pertanian Bogor. $63 \mathrm{p}$

Atmaja, S. B., J. Haluan, \& A. Fauzi. 2002. Dinamika perikanan purse seine di Laut Jawa dan sekitarnya. Seminar Pascasarjana TKL Institut Pertanian Bogor. 18 p.

Atmaja, S. B., Niahasisworo, Suwarso, \& T. Haryati. 2003. Pengkajian stok ikan di wilayah pengelolaan perikanan Laut Jawa. Prosiding, Forum Pengkajian Stok Ikan Laut 2003. Pusat Riset Perikanan Tangkap. Badain Riset Kelautan dan Perikanan. Departemen Kelautan dan Perikanan. 21.p.

Caddy, J. F. \& R. Mcgarney. 1996. Targets or limits for management of fisheries. North American Journal Fisheries Management. American Fisheries Society Vol. 16 (3): 479-487.
Charles, T. A. 2001. Sustainable fishery systems. Blackwell Science Ltd. London. 370 p.

Collier, W. L. 1981. Budi daya ikan dan perikanan rakyat. Dalam Marahudin \& I. R. Smith (Eds.). Ekonomi Perikanan. Yayasan Obor Indonesia dan PT. Gramedia. Jakarta. 281-307.

Cunningham, S. 1981. The evolution of objectives of fisheries management during the 1970'S. Ocean Management. Vol.(6): 251-278.

Fauzi, A. 2000. Teori ekonomi sumber daya perikanan. Paper dari bagian ekonomi sumber daya alam. Institut Pertanian Bogor. Bogor

Garcia, S. 1986. Seasonal trawling bans can be very successful in heavily over fishing area: the cyprus effect. Fishbyte Vol.4 (1): 7-12.

Hilborn, R. \& C. J. Walters. 1992. Quantitative fisheries stock assessment: Choice, dynamics, and uncertainty. Chapman and Hall. New York, London. $570 \mathrm{p}$

McElroy, J. K., J. Rogers, \& C. Tample. 1991 Proposed project programme incorporating report of field visit to project area. First technical report of 01/91. Landell Mills Limited. ALAINS/87/17. 42 p.

Nurhakim, S., B. Sadhotomo, \& M. Potier. 1995 Composite model on small pelagic resources. In Potier \& S. Nurhakim, editor: Biodynex. Seminar Biology, Dynamics, and Exploitation of small pelagic in Java Sea. Jakarta, 21-25 March 1994 EECIAARD/ORSTOM. 145-153.

Laevastu, T. \& F. Favorite. 1988. Fishing and stock fluktuation. Fishing New Books. England. $239 \mathrm{p}$

Sujastani, T. 1978. Perhitungan besarnya stock sumber-sumber perikanan di Laut Jawa berdasarkan data statistik perikanan daerah. Simposium Modernisasi Perikanan Rakyat. 
Lampiran 1. Perkembangan produksi ikan dan upaya penangkapan pukat cincin di tempat penangkapan ikan Pekalongan dan Juana, selama tahun 1976 sampai dengan 2004

Appendix 1. The development of total production of fish and effort of purse seine in Pekalongan and Juana landing place, during the periods 1976 to 2004

\begin{tabular}{|c|c|c|c|}
\hline Tahun & Trip & Hari & Produksi (ton) \\
\hline 1976 & 3.930 & 15.720 & 10.899 \\
\hline 1977 & 4.625 & 18.500 & 12.740 \\
\hline 1978 & 5.760 & 28.800 & 17.236 \\
\hline 1979 & 5.950 & 35.059 & 21.231 \\
\hline 1980 & 5.918 & 39.236 & 24.303 \\
\hline 1981 & 5.389 & 43.542 & 21.720 \\
\hline 1982 & 5.935 & 48.492 & 28.273 \\
\hline 1983 & 5.896 & 55.327 & 45.807 \\
\hline 1984 & 5.709 & 63.511 & 56.264 \\
\hline 1985 & 5.132 & 55.931 & 82.824 \\
\hline 1986 & 4.702 & 63.484 & 83.003 \\
\hline 1987 & 3.948 & 60.465 & 59.503 \\
\hline 1988 & 3.709 & 56.865 & 47.884 \\
\hline 1989 & 4.173 & 59.636 & 65.660 \\
\hline 1990 & 3.914 & 54.532 & 71.903 \\
\hline 1991 & 4.098 & 60.569 & 102.780 \\
\hline 1992 & 4.537 & 73.221 & 129.719 \\
\hline 1993 & 4.230 & 76.929 & 115.217 \\
\hline 1994 & 4.476 & 83.525 & 144.200 \\
\hline 1995 & 4.231 & 90.267 & 123.386 \\
\hline 1996 & 4.538 & 103.283 & 110.278 \\
\hline 1997 & 3.890 & 90.760 & 115.405 \\
\hline 1998 & 4.331 & 99.370 & 118.077 \\
\hline 1999 & 3.610 & 88.457 & 85.914 \\
\hline 2000 & 3.304 & 89.244 & 82.952 \\
\hline 2001 & 3.075 & 87.240 & 93.622 \\
\hline 2002 & 4.134 & 120.296 & 85.337 \\
\hline 2003 & 3.900 & 114.937 & 83.936 \\
\hline 2004 & 3.547 & 104.559 & 79.029 \\
\hline
\end{tabular}


Lampiran 2. Biaya operasional dan harga ikan dari hasil tangkapan pukat cincin Appendix 2. Operational cost and price of fish from purse seine catch

\begin{tabular}{|c|c|c|c|c|c|c|}
\hline \multirow[t]{2}{*}{ Nama kapal } & \multirow{2}{*}{$\begin{array}{c}\text { Blaya operasional } \\
\text { Rp. }(1000)\end{array}$} & \multirow[t]{2}{*}{ Harl laut } & \multicolumn{2}{|c|}{ Total produksi } & Blaya per hari & $\begin{array}{c}\text { Harga lkan } \\
\text { perton }\end{array}$ \\
\hline & & & $\mathrm{Kg}$ & Rp. $(1000)$ & & Rp. $(1000)$ \\
\hline Adl Surya & 45 & 35 & 53.774 & 217.597 & 1,286 & 4,047 \\
\hline Bintang Mas Champion & 50 & 53 & 31.991 & 102.346 & 0,943 & 3,199 \\
\hline Colombia & 50 & 38 & 33.867 & 114.196 & 1,316 & 3,372 \\
\hline Comando & 50 & 36 & 10.086 & 17.483 & 1,389 & 1,733 \\
\hline Indah Makmur & 47 & 37 & 25.180 & 75.482 & 1.270 & 2,998 \\
\hline Jasa Mina Makmur Jaya & 60 & 53 & 51.900 & 194.365 & 1,132 & 3,745 \\
\hline Mitra Utama-D & 40 & 43 & 19.165 & 79.706 & 0,930 & 4,159 \\
\hline Sido Mumbul Jaya lii & 60 & 25 & 29.645 & 97.488 & 2,400 & 3,289 \\
\hline Charly Haslindo Utama & 60 & 46 & 62.138 & 124.598 & 1,304 & 2,005 \\
\hline Gabungan Jaya Mina & 60 & 67 & 32.178 & 84.942 & 1,053 & 2,640 \\
\hline Surya Mas & 60 & 66 & 38.803 & 118.339 & 0,909 & 3,050 \\
\hline Sampurna United & 60 & 63 & 41.763 & 121.019 & 0,952 & 2.898 \\
\hline Jasa Mina Makmur & 50 & 49 & 28.682 & 56.087 & 1,020 & 1.955 \\
\hline Surya Mantap & 50 & 21 & 24.810 & 68.335 & 2,381 & 2.754 \\
\hline Mitra Utama Rejeki & 50 & 52 & 31.335 & 78.485 & 0,962 & 2.505 \\
\hline Discovery & 45 & 54 & 12.467 & 42.874 & 0,833 & 3,439 \\
\hline Langsung Jaya Makmur & 55 & 62 & 35.264 & 95.555 & 0,887 & 2,710 \\
\hline Bintang Mas Berlian & 55 & 53 & 17.952 & 72.569 & 1,038 & 4,042 \\
\hline Bintang Mas Union & 55 & 50 & 10.757 & 35.114 & 1,100 & 3,264 \\
\hline Ajle Mina Perkasa & 45 & 37 & 18.247 & 111.989 & 1,216 & 6,137 \\
\hline Fajar Mulia & 50 & 53 & 24.191 & 88.497 & 0,943 & 3,658 \\
\hline Mahkota Mustika Makmur & 50 & 41 & 33.614 & 60.929 & 1,220 & 1,813 \\
\hline Kasin Setia-Xi & 60 & 59 & 21.435 & 56.214 & 1,017 & 2,623 \\
\hline Sari Utama & 50 & 54 & 14.754 & 49.060 & 0,926 & 3,325 \\
\hline Bintang Mas United & 50 & 58 & 5.599 & 44.660 & 0,862 & 7,976 \\
\hline Bintang Mas Utama & 50 & 58 & 4.521 & 18.380 & 0,862 & 4,065 \\
\hline Bintang Sumber Prima & 35 & 41 & 22.729 & 73.686 & 0,854 & 3,242 \\
\hline Bintang Mas Sukses & 60 & 53 & 38.428 & 150.642 & 1,132 & 3,920 \\
\hline Berkan Bahari & 70 & 39 & 18.845 & 60.510 & 1,795 & 3,211 \\
\hline Bintang Agrindo Prima & 50 & 34 & 33748 & 177.229 & 1,471 & 5,252 \\
\hline Sinar Timur & 25 & 15 & 23.876 & 67.079 & 1,667 & 2,809 \\
\hline Bintang Mas Diamond & 50 & 57 & 17901 & 46.847 & 0,877 & 2,617 \\
\hline Patriot & 55 & 41 & 36.444 & 138.506 & 1,341 & 3,801 \\
\hline Bintang Mas Mutiara & 50 & 44 & 18.849 & 45.214 & 1,136 & 2,399 \\
\hline Bayu Makmur & 50 & 29 & 45.505 & 107.346 & 1.724 & 2,359 \\
\hline Kasih Setia-10 & 40 & 26 & 27.083 & 71.294 & 1,538 & 2,632 \\
\hline Jasa Mina Makmur & 60 & 27 & 52.911 & 90.860 & 2,222 & 1,717 \\
\hline Bintang Sumber Jaya-8 & 45 & 27 & 26.182 & 42.453 & 1.667 & 1,621 \\
\hline Megah Indah & 55 & 37 & 38.313 & 85.356 & 1.486 & 2,228 \\
\hline Modern-1 & 50 & 31 & 28240 & 75.703 & 1,613 & 2,681 \\
\hline Continental & 60 & 30 & 53.073 & 134.934 & 2.000 & 2,542 \\
\hline Bintang Sinar Rejeki & 55 & 16 & 49.815 & 128.569 & 3,438 & 2,581 \\
\hline Sampurna Jaya Raya & 55 & 14 & 44.182 & 126.512 & 3,929 & 2,863 \\
\hline Prima Surya & 65 & 22 & 56.546 & 100.620 & 2,955 & 1,779 \\
\hline Ajle Mina Perkasa & 50 & 16 & 103.089 & 291.480 & 3,125 & 2.827 \\
\hline Amry Mina Perkasa & 66 & 24 & 47.354 & 129.160 & 2,750 & 2,728 \\
\hline Ariane & 66 & 29 & 25.121 & 72.483 & 2,276 & 2,885 \\
\hline Banyu Urip Agung & 60 & 28 & 58.581 & 160.472 & 2,143 & 2,739 \\
\hline Citra Jawa Agung-1 & 50 & 14 & 29.736 & 94.457 & 3,571 & 3,177 \\
\hline Bintang Anugerah & 50 & 15 & 31.247 & 118.106 & 3,333 & 3780 \\
\hline Jasa Mina Rejeki & 60 & 25 & 55.604 & 177.619 & 2,400 & 3,194 \\
\hline Mina Fajar Mustika & 40 & 11 & 42.334 & 142.406 & 3,636 & 3.364 \\
\hline Mahkota Makin Makmur & 60 & 35 & 19.271 & 57.160 & 1,714 & 2,966 \\
\hline Mitra Utama Rejeki & 50 & 20 & 8.428 & 31.452 & 2,500 & 3,732 \\
\hline Modern & 70 & 30 & 66.892 & 159.405 & 2,333 & 2.383 \\
\hline Puwer Utama & 55 & 35 & 17.477 & 64.020 & 1,571 & 3,663 \\
\hline Risky Adi Mina & 60 & 28 & 30.725 & 53.375 & 2,143 & 1,737 \\
\hline Surya Kartika Candra & 60 & 22 & 40.406 & 125.957 & 2,727 & 3,117 \\
\hline Sinar Jaya Sejahtera & 40 & 18 & 23.615 & 62.795 & 2,222 & 2,659 \\
\hline Sinar Laut & 55 & 22 & 16.366 & 50193 & 2,500 & 3.067 \\
\hline Sinar Kencana & 60 & 25 & 16.339 & 77.045 & 2,400 & 4,715 \\
\hline Sinar Fajar-8 & 55 & 25 & 14.041 & 48.796 & 2,200 & 3,475 \\
\hline Sinar Buana & 60 & 26 & 52.978 & 176.240 & 2,308 & 3,327 \\
\hline Bayu Urip Agung & 60 & 25 & 51.709 & 137.862 & 2,400 & 2.666 \\
\hline Pelita Perkasa & 55 & 17 & 39.956 & 85.533 & 3,235 & 2,141 \\
\hline Bintang Mas Delima & 55 & 33 & 33.275 & 121.717 & 1,667 & 3,658 \\
\hline Mitra Cipta Jaya & 35 & 14 & 33.910 & 89.985 & 2,500 & 2,654 \\
\hline Bintang Mas Sampurna & 48 & 40 & 30.033 & 55.713 & 1,200 & 1,855 \\
\hline Bintang Mas Santika & 60 & 38 & 35.196 & 54411 & 1,579 & 1,546 \\
\hline Prima Arindo-2 & 60 & 23 & 87.726 & 201.232 & 2,609 & 2,294 \\
\hline Cahaya Surya & 50 & 33 & 58.130 & 124.430 & 1,515 & 2,141 \\
\hline Bintang Mas Harapan & 50 & 20 & 40.648 & 105.772 & 2,500 & 2,602 \\
\hline Kasih Setia-8 & 70 & 42 & 78.645 & 141.038 & 1,667 & 1,793 \\
\hline Megah Jaya & 60 & 35 & 43.168 & 82.846 & 1,714 & 1.919 \\
\hline Bintang Mas Pratama & 50 & 15 & 45.841 & 104.911 & 3,333 & 2,289 \\
\hline Amalia Mina Oerkasa & 50 & 16 & 57.302 & 84.334 & 3,125 & 1,472 \\
\hline Bintang Sumber Jaya-9 & 60 & 26 & 48.120 & 81.373 & 2,308 & 1,691 \\
\hline Citra Armina & 40 & 14 & 15.593 & 57.023 & 2,857 & 3,657 \\
\hline Mitra Utama Sejati & 45 & 22 & 86.698 & 173.085 & 2,045 & 1,996 \\
\hline Dinasty Satu & 60 & 24 & 49.664 & 122.515 & 2,500 & 2,467 \\
\hline Rata-rata & & & & & 1,870 & 2,950 \\
\hline
\end{tabular}


Lampiran 3. Aktivitas kapal margo selama tahun 2002 sampai dengan 2004

Appendix 3. Activities of Margo vessel during the periods 2002 to 2004

\begin{tabular}{|c|c|c|c|c|c|c|c|c|c|}
\hline Margo & $\begin{array}{c}\text { Tgl } \\
\text { masuk }\end{array}$ & Bulan & $\begin{array}{l}\text { Produksi } \\
\text { (ton) }\end{array}$ & $\begin{array}{c}\text { Nilai } \\
\text { produksi } \\
(x \\
\text { Rp.1000) }\end{array}$ & Margo & $\begin{array}{c}\text { Tgl } \\
\text { masuk }\end{array}$ & Bulan & $\begin{array}{l}\text { Produksi } \\
\text { (ton) }\end{array}$ & $\begin{array}{c}\text { Nilai } \\
\text { produksi } \\
(x \\
\text { Rp. } 1000)\end{array}$ \\
\hline Abadi & 18 & 3 & 1.405 & 5.665 & Luhur & 28 & 6 & 29.565 & 117.485 \\
\hline Abadi & 10 & 4 & 3.483 & 14.975 & Luhur & 18 & 7 & 49.329 & 114.100 \\
\hline Abadi & 18 & 7 & 36.180 & 73.195 & Luhur & 21 & 8 & 12.690 & 18.385 \\
\hline Abadi & 22 & 8 & 21.060 & 50.705 & Luhur & 6 & 9 & 31.752 & 98.625 \\
\hline Abadi & 26 & 9 & 28.350 & 93.665 & Luhur & 25 & 10 & 6.426 & 23.895 \\
\hline Abadi & 26 & 10 & 29.565 & 98.920 & Luhur & 4 & 11 & 22.345 & 65.245 \\
\hline Abadi & 25 & 11 & 7.452 & 33.325 & Lumitu & 7 & 3 & 6.670 & 22.425 \\
\hline Agung & 23 & 2 & 14.013 & 80.695 & Lumintu & 11 & 7 & 19.683 & 40.410 \\
\hline Agung & 14 & 6 & 1.134 & 8.040 & Lumintu & 2 & 9 & 24.300 & 62.315 \\
\hline Agung & 28 & 6 & 23.895 & 96.345 & Makmur & 17 & 3 & 15.930 & 47.640 \\
\hline Agung & 7 & 8 & 17.928 & 36.190 & Makmur & 29 & 7 & 22.545 & 66.370 \\
\hline Agung & 4 & 10 & 29.295 & 83.785 & Makmur & 18 & 8 & 32.400 & 103.195 \\
\hline Agung & 28 & 10 & 7.020 & 26.005 & Makmur & 13 & 9 & 38.340 & 116.080 \\
\hline Agung & 19 & 11 & 19.494 & 70.150 & Makmur & 15 & 10 & 24.300 & 118.710 \\
\hline Anugrah & 23 & 2 & 6.615 & 27.750 & Makmur & 15 & 11 & 24.300 & 96.905 \\
\hline Anugrah & 30 & 6 & 6.426 & 30.800 & Mandiri & 11 & 3 & 4.860 & 14.055 \\
\hline Anugrah & 16 & 7 & 17.631 & 43.000 & Mandiri & 10 & 6 & 20.520 & 89.035 \\
\hline Anugrah & 7 & 9 & 28.438 & 64.055 & Mandiri & 19 & 7 & 22.275 & 104.745 \\
\hline Anugrah & 28 & 10 & 30.699 & 97.335 & Mandiri & 12 & 9 & 37.395 & 112.855 \\
\hline Anugrah & 25 & 11 & 8.100 & 37.700 & Mandiri & 16 & 10 & 4.860 & 16.830 \\
\hline Anugrah & 1 & 12 & 18.232 & 19.503 & Mandiri & 29 & 10 & 27.999 & 75.960 \\
\hline Birowo & 14 & 2 & 12.150 & 45.265 & Mandiri & 12 & 12 & 22.140 & 27.725 \\
\hline Birowo & 8 & 7 & 28.080 & 72.730 & Nugroho & 20 & 2 & 10.800 & 31.560 \\
\hline Birowo & 14 & 8 & 35.424 & 94.925 & Nugroho & 1 & 4 & 11.610 & 48.285 \\
\hline Birowo & 15 & 9 & 39.420 & 95.725 & Nugroho & 1 & 6 & 14.337 & 74.585 \\
\hline Birowo & 16 & 10 & 26.190 & 108.055 & Nugroho & 1 & 7 & 8.505 & 36.465 \\
\hline Birowo & 29 & 10 & 6.534 & 26.700 & Nugroho & 12 & 7 & 11.502 & 39.770 \\
\hline Birowo & 16 & 11 & 33.075 & 142.854 & Nugroho & 21 & 8 & 23.200 & 86.043 \\
\hline Kaloko & 7 & 2 & 6.093 & 33.360 & Nugroho & 3 & 10 & 45.090 & 109.395 \\
\hline Kaloko & 28 & 3 & 12.184 & 47.635 & Nugroho & 10 & 11 & 34.820 & 120.005 \\
\hline Kaloko & 28 & 5 & 2.025 & 9.660 & Purnomo & 19 & 3 & 8.262 & 30.330 \\
\hline Kaloko & 14 & 6 & 16.470 & 79.595 & Purnomo & 28 & 5 & 20.574 & 88.480 \\
\hline Kaloko & 24 & 7 & 28.350 & 68.625 & Purnomo & 15 & 7 & 38.313 & 128.560 \\
\hline Kaloko & 15 & 9 & 4.050 & 22.095 & Purnomo & 13 & 9 & 51.354 & 104.835 \\
\hline Kaloko & 28 & 9 & 2.295 & 68.640 & Purnomo & 6 & 10 & 324 & 1.430 \\
\hline Kaloko & 19 & 10 & 5.886 & 35.150 & Purnomo & 4 & 11 & 18.320 & 30.090 \\
\hline Kaloko & 26 & 10 & 945 & 4.355 & Purnomo & 26 & 11 & 5.400 & 24.550 \\
\hline Kaloko & 18 & 11 & 33.750 & 92.425 & Rejeki & 8 & 7 & 23.760 & 68.460 \\
\hline Koncoro & 11 & 3 & 32.265 & 118.080 & Rejeki & 17 & 8 & 10.800 & 20.040 \\
\hline Kencono & 29 & 5 & 24.003 & 124.425 & Rejeki & 17 & 10 & 1.620 & 8.740 \\
\hline Kencono & 13 & 6 & 20.763 & 87.380 & Rejeki & 28 & 10 & 22.518 & 80.540 \\
\hline Kencono & 2 & 7 & 26.136 & 99.995 & Rejeki & 26 & 11 & 14.166 & 76.525 \\
\hline Kencono & 17 & 7 & 47.250 & 120.170 & Waluyo & 15 & 2 & 16.524 & 85.230 \\
\hline Kencono & 6 & 8 & 45.576 & 94.965 & Waluyo & 30 & 3 & 8.100 & 31.765 \\
\hline Kencono & 8 & 9 & 37.071 & 95.170 & Waluyo & 30 & 3 & 6.507 & 18.660 \\
\hline Kencono & 19 & 9 & 56.322 & 156.395 & Waluyo & 19 & 7 & 1.350 & 3.010 \\
\hline Kencono & 25 & 10 & 38.232 & 114.255 & Waluyo & 20 & 8 & 21.465 & 99.940 \\
\hline Kencono & 8 & 11 & 65.853 & 155.830 & Waluyo & 7 & 8 & 20.304 & 27.750 \\
\hline Kencono & 18 & 11 & 3.105 & 11.375 & Waluyo & 24 & 9 & 15.525 & 46.910 \\
\hline Lestari & 11 & 8 & 15.390 & 33.585 & Waluyo & 4 & 10 & 30.996 & 60.360 \\
\hline Lestari & 26 & 10 & 6.426 & 23.650 & Waluyo & 11 & 12 & 39.285 & 60.160 \\
\hline Lestari & 9 & 11 & 16.200 & 52.015 & Wibowo & 17 & 9 & 41.040 & 106.185 \\
\hline Luhur & 23 & 2 & 10.800 & 70.335 & Wibowo & 4 & 11 & 26.325 & 73.555 \\
\hline Luhur & 30 & 3 & 7.665 & 28.660 & Wijaya & 25 & 8 & 13.500 & 25.975 \\
\hline Luhur & 9 & 4 & 12.825 & 31.495 & & & & & \\
\hline
\end{tabular}




\begin{tabular}{|c|c|c|c|c|c|c|c|c|c|}
\hline \multicolumn{5}{|c|}{ Tahun 2003} & \multicolumn{5}{|c|}{ Tahun 2004} \\
\hline Margo & $\begin{array}{c}\text { Tgl } \\
\text { masuk }\end{array}$ & Bulan & $\begin{array}{l}\text { Produksi } \\
\text { (ton) }\end{array}$ & $\begin{array}{c}\text { Nilai } \\
\text { produksi } \\
(x \\
\text { Rp.1000) } \\
\end{array}$ & Margo & $\begin{array}{c}\text { Tgl } \\
\text { masuk }\end{array}$ & Bulan & $\begin{array}{l}\text { Produksi } \\
\text { (ton) }\end{array}$ & $\begin{array}{c}\text { Nilai } \\
\text { produksi } \\
(x \\
\text { Rp. } 1000)\end{array}$ \\
\hline Anugrah & 6 & 2 & 31.860 & 105.835 & Nugroho & 10 & 1 & 43.632 & 190.345 \\
\hline Anugrah & 10 & 4 & 12.852 & 44.275 & Nugroho & 10 & 2 & 7.587 & 32.685 \\
\hline Anugrah & 2 & 5 & 5.400 & 17.300 & Nugroho & 9 & 4 & 6.480 & 19.615 \\
\hline Kaloko & 7 & 1 & 945 & 6.050 & Nugroho & 16 & 4 & 4.050 & 14.335 \\
\hline Kaloko & 2 & 2 & 4.590 & 8.650 & Nugroho & 3 & 5 & 5.805 & 16.280 \\
\hline Kaloko & 10 & 2 & 14.850 & 50.760 & Nugroho & 30 & 8 & 22.950 & 59.015 \\
\hline Kaloko & 17 & 3 & 6.453 & 44.880 & Purnomo & 10 & 2 & 22.140 & 63.130 \\
\hline Kaloko & 7 & 4 & 17.955 & 50.940 & Purnomo & 17 & 3 & 504 & 6.730 \\
\hline Kaloko & 5 & 5 & 4.941 & 34.410 & Purnomo & 7 & 4 & 21.600 & 83.488 \\
\hline Kaloko & 16 & 10 & 52.380 & 200.705 & Purnomo & 14 & 6 & 12.231 & 43.610 \\
\hline Kaloko & 4 & 11 & 820 & 915 & Purnomo & 13 & 8 & 4.320 & 21.780 \\
\hline Kaloko & 23 & 11 & 14.580 & 36.240 & Purnomo & 24 & 8 & 35.505 & 91.525 \\
\hline Kencono & 9 & 2 & 35.937 & 166.890 & Purnomo & 4 & 10 & 32.535 & 81.975 \\
\hline Kencono & 9 & 4 & 38.124 & 124.510 & Purnomo & 6 & 11 & 24.300 & 66.625 \\
\hline Kencono & 4 & 5 & 20.520 & 103.430 & Rejeki & 19 & 1 & 5184 & 28.655 \\
\hline Kencono & 13 & 8 & 8.748 & 32.395 & Rejeki & 6 & 2 & 18.090 & 61.385 \\
\hline Kencono & 21 & 8 & 33.075 & 105.415 & Agung & 22 & 9 & 19.791 & 37.490 \\
\hline Kencono & 26 & 8 & 42.822 & 106.610 & Agung & 31 & 10 & 44.172 & 83.915 \\
\hline Kencono & 8 & 10 & 60.804 & 172.100 & Agung & 20 & 12 & 36.531 & 93.310 \\
\hline Kencono & 4 & 11 & 6.750 & 20.395 & Anugrah & 27 & 1 & 18.900 & 61.775 \\
\hline Kencono & 15 & 11 & 24.300 & 65.115 & Anugrah & 29 & 9 & 35.397 & 106.695 \\
\hline Kencono & 21 & 11 & 28.890 & 86.075 & Anugrah & 28 & 10 & 30.456 & 66.825 \\
\hline Lestari & 8 & 2 & 12.150 & 40.075 & Anugrah & 26 & 12 & 1.080 & 3.700 \\
\hline Luhur & 8 & 2 & 17.550 & 55.825 & Kaloko & 19 & 1 & 24.975 & 82.645 \\
\hline Luhur & 4 & 4 & 8.154 & 36.645 & Kencoro & 23 & 1 & 63.450 & 196.055 \\
\hline Luhur & 14 & 4 & 25.920 & 131.065 & Kencoro & 15 & 9 & 49.248 & 144.220 \\
\hline Luhur & 12 & 6 & 9.450 & 54.825 & Kencoro & 29 & 9 & 11.394 & 43.105 \\
\hline Luhur & 13 & 8 & 8.910 & 26.210 & Kencoro & 23 & 12 & 56.646 & 192.718 \\
\hline Luhur & 20 & 8 & 34.479 & 91.785 & Kuncoro & 4 & 11 & 91.935 & 170.780 \\
\hline Luhur & 1 & 9 & 46.737 & 172.240 & Luhur & 28 & 1 & 17.550 & 17.550 \\
\hline Luhur & 9 & 10 & 26.325 & 94.615 & Luhur & 14 & 10 & 39.015 & 99.680 \\
\hline Luhur & 4 & 11 & 514 & 870 & Luhur & 27 & 12 & 22.950 & 74.540 \\
\hline Luhur & 17 & 11 & 34.020 & 84.965 & Purnomo & 8 & 10 & 42.930 & 107.525 \\
\hline Makmur & 9 & 2 & 16.848 & 49.688 & Purnomo & 6 & 11 & 43.497 & 82.335 \\
\hline Mandiri & 9 & 2 & 11.475 & 30.655 & & & & & \\
\hline
\end{tabular}

